NO. 120

DECEMBER

2019

\section{ADB BRIEFS}

\section{KEY POINTS}

- This study presents an investment-oriented strategy for improving the per capita income of Uttar Pradesh from $50 \%$ of the national average at present to $75 \%$ by $2032 / 33$, with better livelihoods, social development, and significant poverty reduction.

- The study adopts a demanddriven approach to promote industrial development and job creation. For accelerated infrastructure investment, 11 priority sectors and 6 employment zones comprising 19 focus districts have been identified. These encompass projects in transport, logistics, power, water supply, sanitation, and skill development.

- A long-term infrastructure investment plan worth nearly $\$ 24$ billion is proposed, comprising 288 projects. Of these, 126 projects with investment worth about $\$ 17$ billion are recommended for prioritization.
ISBN 978-92-9261-922-0 (print) ISBN 978-92-9261-923-7 (electronic) ISSN 2071-7202 (print)

ISSN 2218-2675 (electronic)

Publication Stock No. BRF190580-2

DOI: http://dx.doi.org/10.22617/BRF190580-2

\title{
Infrastructure and Investment Planning for Inclusive Growth in Uttar Pradesh
}

\author{
Sabyasachi Mitra \\ Asian Development Bank
}

Mitali Nikore

Consultant

\author{
Kanupriya Gupta \\ Asian Development Bank
}

\section{MACROECONOMIC ANALYSIS: PLACING UTTAR PRADESH IN THE NATIONAL CONTEXT}

Uttar Pradesh occupies a significant place in the Indian economy. Apart from being the most populous state, accounting for approximately $16 \%$ of India's population, Uttar Pradesh is also the third largest contributor to national output (8\% of India's gross domestic product).' However, the gap between its per capita income and the national average has widened consistently since 2005 , such that its per capita income stood at less than $50 \%$ of the national average in $2017 / 18 .^{2}$

A major factor underlying the slow growth and high poverty rates in Uttar Pradesh is the structure of its economy. Agriculture still accounts for a quarter of the state's output. ${ }^{3}$ The share of manufacturing in the gross state domestic product (GSDP) of Uttar Pradesh has declined from $12.9 \%$ in $2011 / 12$ to $10.3 \%$ in $2017 / 18 .{ }^{4}$ Overall, labor productivity in Uttar Pradesh (measured as output per worker) is around $50 \%$ of labor productivity in the rest of India, and wages tend to be $14.0 \%$ lower than the all-India level $(2015 / 16))^{5}$

Reserve Bank of India. 2018. RBI Handbook of Statistics for 2017-18. 5 May. Mumbai, Maharashtra. Also, Government of India. Ministry of Statistics and Program Implementation. Central Statistical Office.

2 Analysis by ADB study team based on data drawn from Government of India. Ministry of Statistics and Program Implementation. www.mospi.gov.in.

3 Data drawn from Government of India. Ministry of Statistics and Program Implementation. Central Statistical Office.

4 Footnote 3.

5 Footnote 2. 


\section{ROAD TO HIGHER, MORE INCLUSIVE GROWTH}

India's annual per capita income is expected to at least treble from the $2017 / 18$ levels to $\$ 6,500$ by $2032 / 33 .{ }^{6}$ If the per capita income of Uttar Pradesh could be improved from $50 \%$ of the national average in 2017/18 (business as usual [BAU]) to around $75 \%$ of the national average in $2032 / 33$, it would result in more productive employment opportunities, greater industrialization, better livelihoods, and significant poverty reduction (Figure 1 and Table 1). However, achieving this would require comprehensive planning and interventions across infrastructure, skill development, urban development, industrial policy, regulatory and governance framework, and fiscal consolidation (business-induced scenario [BIS]).

Figure 1: Road to Higher Per Capita Income in 2032/33 (in \$)

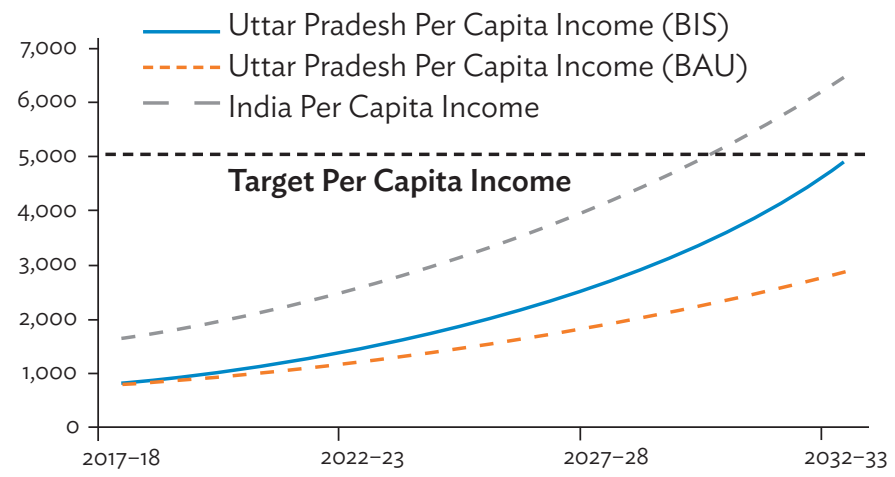

BAU = business as usual; BIS = business-induced scenario Source: Analysis by ADB study team based on data drawn from Government of India. Ministry of Statistics and Program Implementation. www.mospi.gov.in.
Achieving $12.8 \%$ growth in per capita income (mentioned in Table 1) would be contingent upon structural transformation and significant growth in key nonagricultural activitiesmanufacturing; construction; finance, real estate, and professional services; and trade, hotel, and restaurant services. Rapid growth in manufacturing and construction would lead to considerable employment creation given their relatively high employment elasticity. The additional annual investment required under BIS would range from ₹0.9 trillion ( $\$ 13.5$ billion) in 2018/19 to ₹15.3 trillion ( $\$ 168.9$ billion) in 2032/33 (Figure 2). ${ }^{8}$

\section{Figure 2: Investment Required under Different Scenarios, $2018 / 19$ to $2032 / 33$}

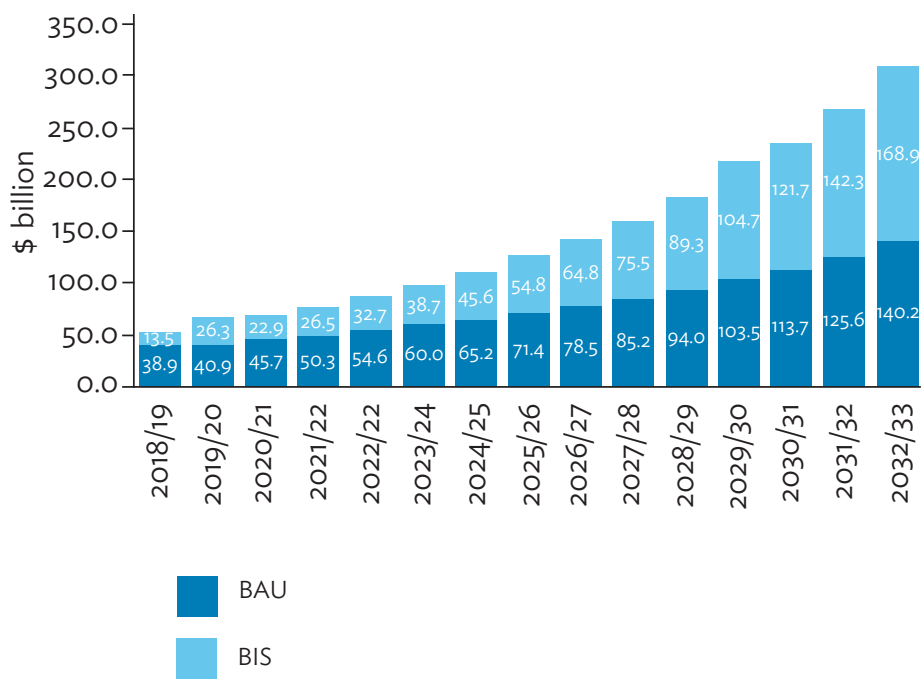

$\mathrm{BAU}=$ business as usual; $\mathrm{BIS}=$ business-induced scenario

Source: Analysis by ADB study team based on data drawn from Government of India. Ministry of Statistics and Program Implementation. www.mospi.gov.in.

\section{Table 1: Performance of Select Economic Indicators by Scenario, 2018/19 to 2032/33}

\begin{tabular}{lcc} 
Economic Indicator & Business-as-Usual Scenario & Business-Induced Scenario \\
Per capita income growth(\%) & 8.9 & 12.8 \\
\hline $\begin{array}{l}\text { Nominal gross state domestic product (GSDP) } \\
\text { growth(\%) }\end{array}$ & 10.5 & 14.5 \\
\hline Real GSDP growth(\%) & 5.7 & 9.5 \\
\hline Gross fixed capital formation (as \% of GSDP) & 20.5 & 27.3 \\
\hline
\end{tabular}

Source: Analysis by ADB study team based on data drawn from Government of India. Ministry of Statistics and Program Implementation. www.mospi.gov.in.

6 Footnote 2.

7 International Labour Organization. 2009. Towards an Employment Strategy for India. www.ilo.org - https://www.ilo.org/wcmsp5/groups/public/---asia/---ro-

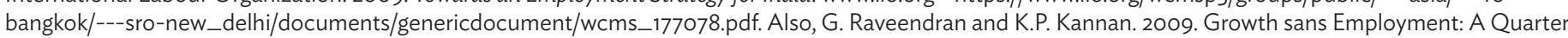
Century of Jobless Growth in India's Organised Manufacturing. Economic and Political Weekly. https://www.epw.in/journal/20og/10/special-articles/growthsans-employment-quarter-century-jobless-growth-indias.

8 In this brief, "₹" refers to Indian rupees and “\$” to United States dollars. A conversion rate of $\$ 1=₹ 70$ is assumed. 


\section{STUDY OBJECTIVES AND IDENTIFICATION OF PRIORITY SECTORS AND ZONES}

In order to support investment-led inclusive growth, an ADB study was undertaken with the objective of identifying key gaps across different infrastructure subsectors including transport, logistics, power, urban, and skill development. ADB adopted a demand-driven approach to identify priority districts and sectors to enable Uttar Pradesh's structural transformation, plug regional imbalances and promote job creation. It was recommended that the government focus on integrated regional development to incentivise organic growth of industrial areas anchored by large firms, and supported by a network of micro, small, and medium enterprises (MSMEs) linked through value chains.
Based on over 200 consultations with key industry and government stakeholders from across the state, the study identified 11 focus sectors for priority investments based on their contribution to current employment, value added, investment, and competitive advantage. The focus sectors are a combination of capitalintensive ones such as electronics, manufacturing, and motor vehicles, and comparatively labor-intensive ones such as leather, textiles and apparels, and food processing. These shortlisted sectors contribute to around $73 \%$ of the state's manufacturing output and $75 \%$ of the total employment in manufacturing. ${ }^{9}$

The study also identified key locations across the state which had the potential to drive the growth of the selected sectors, mitigate regional imbalances, and enable employment generation. Districts were categorized according to their current economic performance

\section{Figure 3: Key Sectors Mapped to Employment Zones}

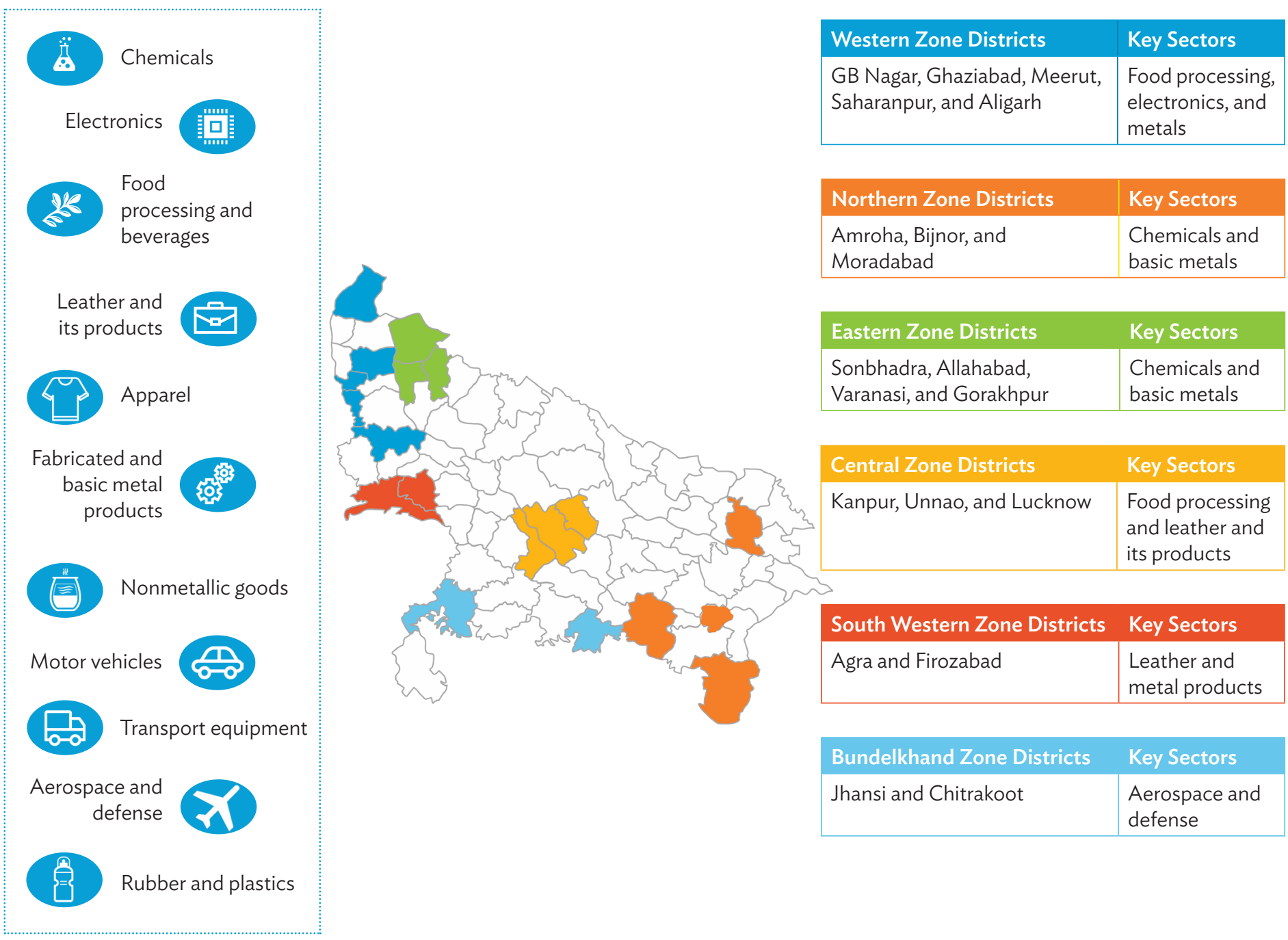

Source: Analysis by ADB study team based on data drawn from the Government of Uttar Pradesh. Analysis by ADB study team based on data drawn from Government of Uttar Pradesh. Directorate of Economics and Statistics. 2016. Annual Survey of Industries
2015-16. http://updes.up.nic.in/esd/Industrial_Statistics/ASI/ASI\%202015-16\%2OREPORT.pdf. 
and the potential to serve as growth centers (based on planned government initiatives in the area). Using this methodology, 6 employment zones were shortlisted across the state, comprising of 19 districts including 5 brownfield zones (western, northern, southwestern, central, and eastern) and 1 greenfield zone (Bundelkhand) (Figure 3).

\section{INDUSTRIAL STRATEGY TO IMPROVE MANUFACTURING COMPETITIVENESS}

The employment zone development framework for Uttar Pradesh (shown in Figure 3) combines industrial planning with infrastructure planning. This is because in order to achieve growth objectives, it is essential to have an industrial development strategy before the related infrastructure and urban development strategies can be formulated. Given that MSMEs account for almost $60 \%$ of the total industrial output in Uttar Pradesh, the study proposed the creation of an "MSME Development Cell" to support cluster-based development."

\section{A Development Cell for Micro, Small, and Medium Enterprises in Each District}

In 2017/18, Uttar Pradesh had the largest number of estimated MSMEs in the country at 8.99 million (a $14.20 \%$ share). ${ }^{11}$ Within the MSME sector, the state's contribution to the total exports from India is $44 \%$ in handicrafts, $39 \%$ in carpets, and $26 \%$ in leather goods. ${ }^{12}$ Several of these MSME clusters face severe challenges in remaining competitive in an increasingly globalized economy (Figure 4). They need strategic interventions aimed not only at infrastructure upgrade but also in terms of access to modern technology, markets, finance, and skills.

While both the national and the state governments have announced several schemes to benefit MSMEs, stakeholder consultations revealed that nearly $30 \%$ of MSME units have failed to avail these benefits owing to limited reach or lack of awareness about such schemes. The state government has launched the MSME Policy 2017 and the One District One Product (ODOP) scheme to support MSMEs through the development of productspecific clusters, in line with a cluster-based development approach. The objective is to enhance product competitiveness by enabling market linkages through joint cluster initiatives.

A dedicated MSME Development Cell in each district to facilitate the effective implementation of cluster-based interventions could create an enabling environment for MSMEs to maximize revenues. Its key functions could include the issuing of policy advisories, promoting technology adoption, assistance in marketing and branding activities (including building "Brand Uttar Pradesh"), capacity building of MSMEs in the region, and

\section{Figure 4: Operational Issues Faced by Micro, Small, and Medium Enterprises in Employment Zones of Uttar Pradesh}

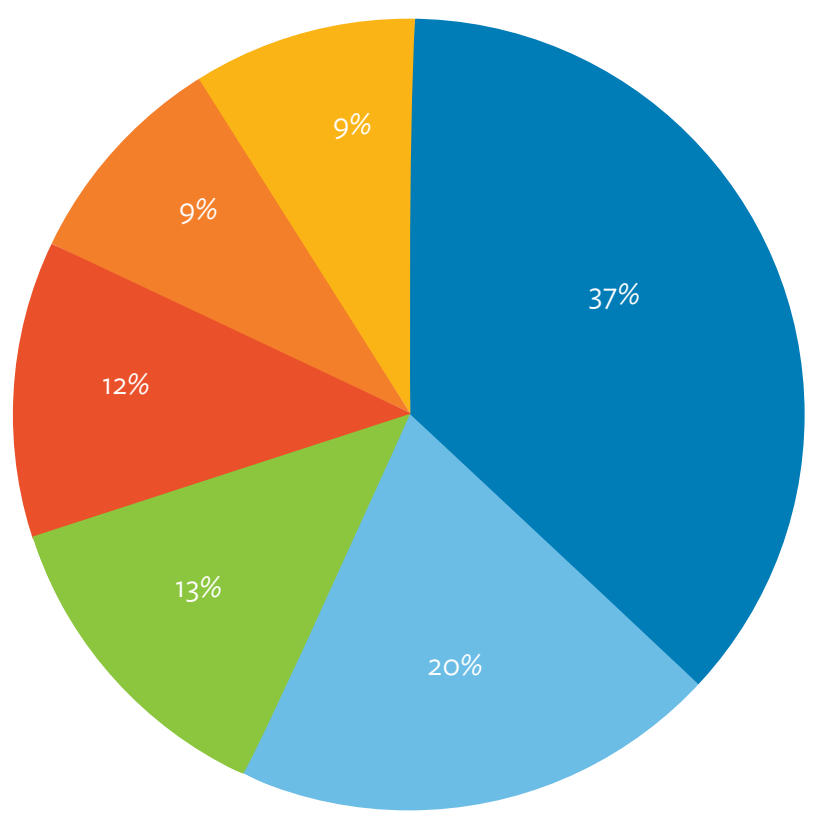

Insufficient power supply

Poor access to finance

Low voltage power

Shortage of raw materials

Lack of trained personnel

Lack of know-how

Source: Government of Uttar Pradesh. Economics and Statistics Division. 2017. Unorganized Manufacturing Enterprises: A Survey Report. 10 November. Lucknow, Uttar Pradesh. Also, stakeholder consultations held by ADB study team.

shared infrastructure development assistance (Figure 5). The MSME Development Cell could be embedded within the District Industries Center, which is the apex body for business facilitation in the district.

The MSME Development Cells will act as accelerators in the districts so that they can provide dedicated, long-term support to MSMEs within the cluster, and devise market access and supply chain solutions to link MSMEs strongly with local, domestic, and global value chains.

Based on an analysis of gross value added, employment, investment trends and government priorities, four sectors-leather, electronics, food processing, and aerospace and defense-emerged as those with significant comparative advantage for Uttar Pradesh. These were therefore selected for detailed value chain assessment.

10 Government of Uttar Pradesh. Economics and Statistics Division. 2017. Unorganized Manufacturing Enterprises: A Survey Report. 10 November. Lucknow, Uttar Pradesh.

"Government of India. Ministry of Micro, Small, and Medium Enterprises. Annual Report 2017-18. New Delhi. p. 35/113, para 2.3.5.

12 Government of Uttar Pradesh. 2018. Empowering Uttar Pradesh: One District One Product Policy. p. 11/92 http://odopup.in/pdf/20180305_ODOP-English. pdf? cd=MQAxADYA. 


\section{Figure 5: Value Proposition of the Development Cell for Micro, Small, and Medium Enterprises}

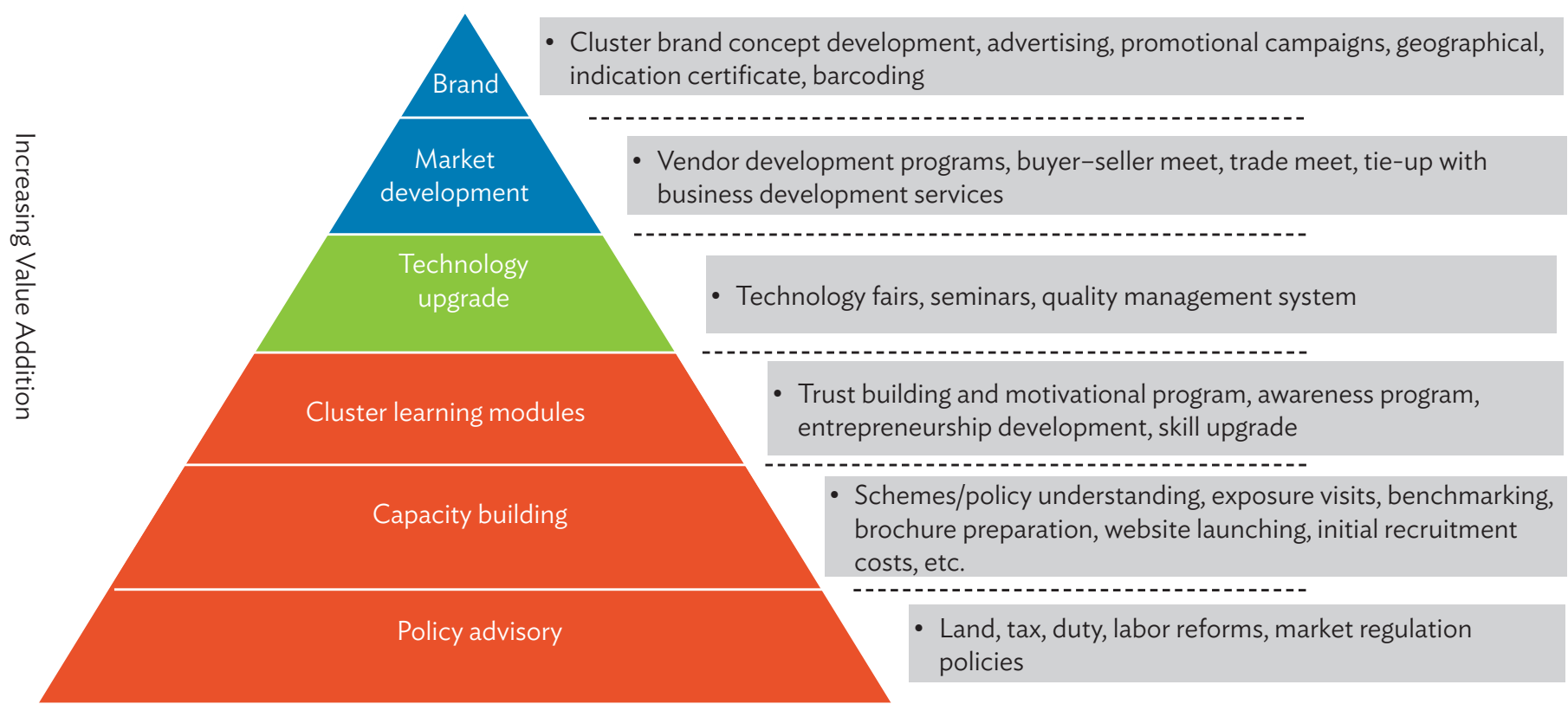

Source: ADB study team analysis.

\section{Key Enablers Identified Through Value Chain}

\section{Assessment of Selected Sectors}

A detailed value chain analysis of the leather, electronics, food processing, and aerospace and defense sectors, was developed within the study, with the twin objectives of mapping their present level of manufacturing competitiveness and identifying opportunities to improve productivity and generate employment (Table 2).

\section{Table 2: Value Chain Analysis of Selected Sectors in Uttar Pradesh}

\begin{tabular}{|c|c|c|}
\hline Sector & Status & Action \\
\hline Leather & $\begin{array}{l}\text { Uttar Pradesh produces more low-value tanned leather and } \\
\text { footwear than high value-added products. } \\
\text { The gross value added-output ratio stands at } 17 \% \text { for Uttar } \\
\text { Pradesh as opposed to the national average of } 20 \% \text {. }\end{array}$ & $\begin{array}{l}\text { Develop dedicated industrial clusters, common infrastructure } \\
\text { facilities, common effluent treatment plants, and branding } \\
\text { support. }\end{array}$ \\
\hline Electronics & $\begin{array}{l}\text { With big investments in electronics (in particular mobile } \\
\text { phone components), the sector in the state grew at a } \\
\text { compounded annual rate of } 27 \% \text { from } 2008 \text { to } 2018 \text {. }\end{array}$ & $\begin{array}{l}\text { Develop the Noida and Greater Noida region as an electronics } \\
\text { components and assembly manufacturing hub. } \\
\text { - Develop market linkages through Jewar airport. } \\
\text { - Focus on parts and components manufacturing and attempt } \\
\text { to bring in suppliers of large foreign and local companies. }\end{array}$ \\
\hline $\begin{array}{l}\text { Dairy } \\
\text { and Food } \\
\text { Processing }\end{array}$ & $\begin{array}{l}\text { While Uttar Pradesh is the largest milk producer across all } \\
\text { Indian states, only } 30 \% \text { dairy production is organized. } \\
\text { - Only } 6 \% \text { of products in Uttar Pradesh are processed, as } \\
\text { compared to the national average of } 10 \% \text {. }\end{array}$ & $\begin{array}{l}\text { Set up mid-scale organized dairy centers, with an average } \\
\text { processing capacity of } 0.5 \text { million liters per day in the } 16 \\
\text { potential locations identified. } \\
\text { Develop irrigation, power supply, transport, and storage } \\
\text { infrastructure. }\end{array}$ \\
\hline $\begin{array}{l}\text { Aerospace } \\
\text { and } \\
\text { Defense }\end{array}$ & $\begin{array}{l}\text { About } 70 \% \text { of the state MSMEs are engaged in activities allied } \\
\text { to aerospace and defense. } \\
\text { A defense corridor is planned in the Bundelkhand region. }\end{array}$ & $\begin{array}{l}\text { Develop OEMs for transport aircraft, small arms, artillery guns, } \\
\text { and handheld electrical devices. } \\
\text { - Set up Tier } 1 \text { or } 2 \text { supplier units for aero structures, electronics, } \\
\text { and spares. } \\
\text { - Establish an MRO hub for land (and air) platforms. } \\
\text { - Promote supplier units for consumables and wearables } \\
\text { including uniforms, bulletproof apparel, and ordnance. }\end{array}$ \\
\hline
\end{tabular}


High transaction costs arising from inadequate and inefficient infrastructure can prevent the economy from realizing its full growth potential. While industries, particularly MSMEs, require cluster infrastructure (e.g., industrial parks, common facilities centers, and skill training centers) to improve the competitiveness of the manufacturing process, they also need trunk infrastructure (e.g., road connectivity and power supply) to promote links with key consumption centers and gateways, and to expand markets. Thus, this study has analyzed various infrastructure subsectors impacting both manufacturing within employment zones, as well as connectivity to gateways and markets.

\section{INFRASTRUCTURE GAPS AND INVESTMENT PLAN}

For a landlocked state such as Uttar Pradesh, access to gateways (such as inland container depots, ports, etc.) which link production centers within the state to key domestic and international markets is essential to link in with global value chains, and boost export growth. The study devised a two-pronged strategy for addressing the infrastructure gap in Uttar Pradesh.

\section{Enhanced transport and access-to-gateways}

infrastructure. Development of a grid of transport projects by focusing on all modes of transport (road, rail, and airports) and projects will enable key storage and access to gateways.

\section{Infrastructure projects for enabling employment}

zones. Better power network, utilities, and skilling solutions will support the development of employment zones.

For a growing economy with a large geographical spread, logistics planning and cost optimization through better transport infrastructure become critical to remain competitive in domestic and global markets. The study found that though Uttar Pradesh has a strong spinal network of highways and expressways, it still needs additional investment in last-mile rail and road connectivity. Logistics and storage facilities, ranging from inland container depots, to warehouses and cold storage facilities, require decongestion, improved connectivity to industrial estates and technology upgrades. Thus, the study recommended setting up multimodal logistics hubs to ease domestic and export-import cargo movement within and outside the state.

The urban population of the state is estimated to reach 66.7 million by 2021, increasing by 22.2 million between 2011 and $2021 .^{13}$ The study undertook an urban planning exercise with a view to spreading out urbanization, managing growing city densities, and harnessing the synergies between urbanization and industrialization. Urban centers act as catalysts to attract resources and services for industries to prosper. Drawing on international experiences, this study recommended a long-term coordinated approach for urban development in the employment zones, prioritizing increasing piped water supply, reducing arsenic and fluoride contamination, and upgrading sewerage and draining infrastructure.

Uttar Pradesh needs to improve availability of reliable and affordable power. Projections indicate that, across consumer categories, energy requirement in Uttar Pradesh will grow at 6\% per annum and the state is expected to meet around $86 \%$ of its annual requirement between 2018/19 and 2021/22, leading to an energy deficit of $14 \% .{ }^{14}$ Deploying renewable energy technologies like solar power can offer quick low-cost solutions to the energy deficit scenario and reduce its overall power purchase cost. Further, regular transformer failures, and high frequency of excessive voltage drops indicate the need for a more robust and reliable transmission and distribution network, with dedicated industrial feeders and substations.

Uttar Pradesh offers a significant demographic dividend for India. Census projections show that by 2026, the state will have the largest working age population, at about 153 million persons. ${ }^{15}$ As labor shortages due to an aging population are experienced around the world, India and thereby Uttar Pradesh, can become a valuable source of labor in an increasingly globalized economy. However, in order to achieve this objective, the abundant labor of Uttar Pradesh needs to be equipped with strong foundation skills. There is a need to create a pipeline of sufficiently trained workers who can meet the growing demand for job roles requiring skilled and semiskilled workers.

Uttar Pradesh continues to face capacity constraints in skill development and training. The study found that each year about 1.2 million youth are unable to find opportunities for skill training or further education. ${ }^{16} \mathrm{It}$ is projected that about 15.8 million jobs will be generated in the state between 2018 and 2028 and more than $70 \%$ of these incremental jobs are likely to be for skilled or semiskilled workers. ${ }^{17}$ However, only $15 \%$ of the total demand is being met through the present pipeline of workers trained in 20142017. In addition to enhancing capacity, the study emphasized the need to improve the relevance of the current training programs, enhance linkages between industry and training, and introduce courses which meet the needs of growing sectors, as also the newer, evolving requirements of more traditional sectors.

A capital-efficient approach for financing priority infrastructure projects was undertaken in the study, to prioritize investment worth $\$ 17$ billion under 126 projects over the short term. Of the total investment required, nearly $50 \%$ is in road development (spinal expressways and last-mile connectivity), followed by urban

13 Data from the Government of Uttar Pradesh

14 Based on analysis of data from Uttar Pradesh Power Corporation Ltd, Central Electricity Authority, Power Finance Corporation.

15 Government of India. Ministry of Home Affairs. Office of the Registrar General and Census Commissioner of India. May 2006. Population projections for India and States (2001-2026).

16 Based on analysis of data from the Uttar Pradesh Skill Development Mission, Department of Higher Education, Government of Uttar Pradesh.

17 Estimates for 2018-2022 taken directly from National Skill Development Corporation (NSDC). 2012. District wise Skill Gap Study for the State of Uttar Pradesh. Available at https://www.nsdcindia.org/sites/default/files/files/up-sg-report.pdf. Estimates for 2023-2028 based on trend analysis of NSDC data, projected using growth rates of incremental jobs across skill categories between the two time periods, 2012-2017 and 2018-2022. 
services (drainage, sewerage, and sanitation), railways, airports, logistics (multimodal parks), power (transmission and distribution), and industrial park infrastructure (Figure 6).

\section{Figure 6: Investment Required across Infrastructure Subsectors (\%)}

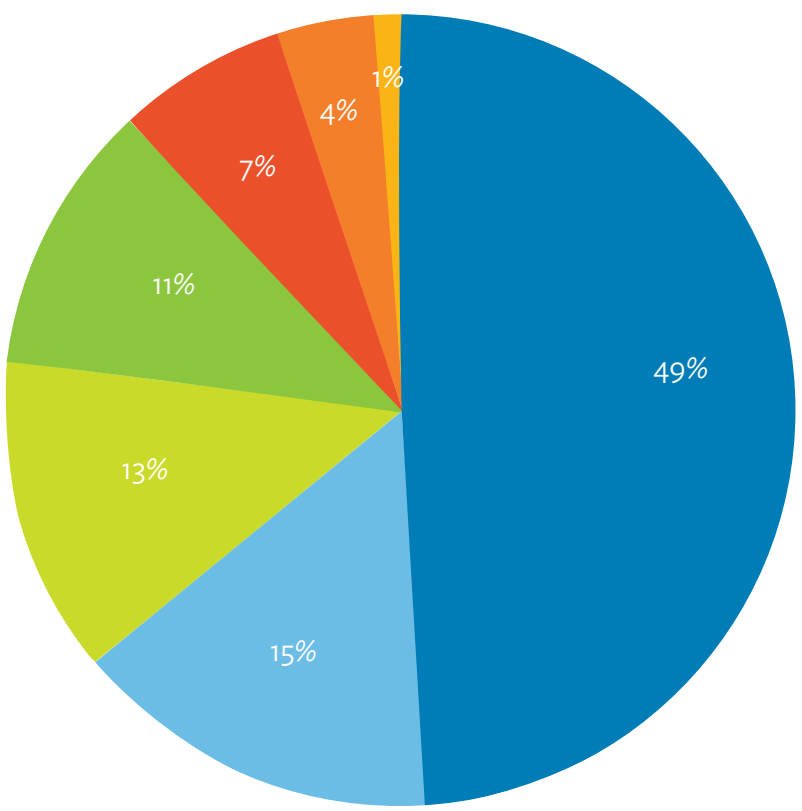

Roads

Urban development

Railways

Airports

Source: Analysis by ADB study team based on projects details provided by the Government of Uttar Pradesh.

Across employment zones, investment requirements are highest in the eastern $(\sim 34 \%)$, followed by the western ( $23 \%)$ and central ( 17\%) zones (Figure 7).

Over 288 projects worth $\$ 24$ billion were identified over the medium to long term across the six employment zones for debottlenecking infrastructure constraints across sectors. These projects seek to address issues such as capacity deficit (through roads connecting the employment zone to spine, last-mile road connectivity etc.); lack of infrastructure (through expressways, new regional airports, multimodal logistics hub and freight villages, etc.); and need for new infrastructure (through trunk infrastructure for cluster development).

\section{Figure 7: Investment Required Across Employment Zones (\$ million)}

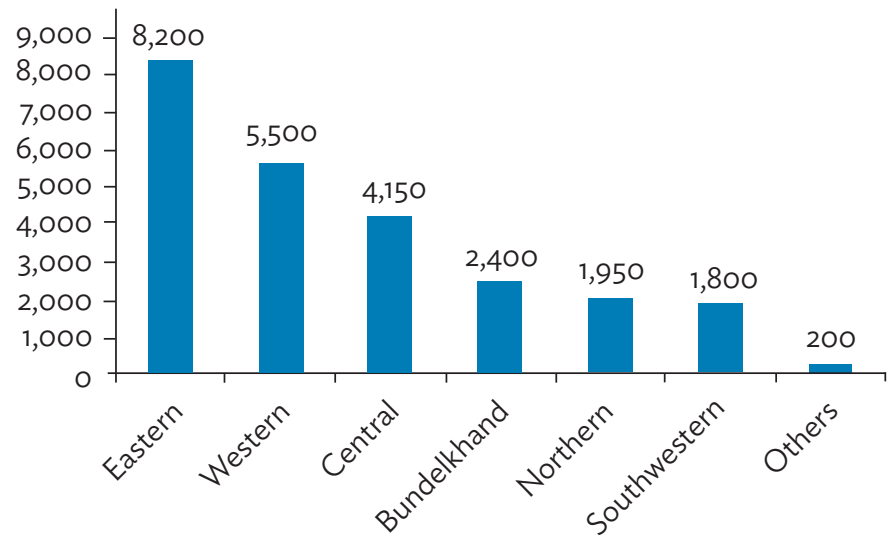

Source: Analysis by ADB study team based on projects details provided by the Government of Uttar Pradesh.

\section{PRIORITY PROJECTS TO CATALYZE CHANGE}

Sector-specific recommendations for priority projects under the investment plan were developed by the ADB study team based on stakeholder consultations and analysis of data provided by the Government of Uttar Pradesh. These are presented below.

\section{Roads}

Investment required: $\$ 11.7$ billion

- Across all state highways and major district roads, 75\% road length requires capacity augmentation.

- To enable last-mile connectivity, 29 road stretches across 10 state highways and 6 major district roads (MDRs) require capacity augmentation.

- The study has identified 55 radial road network projects connecting employment zones with key expressways and national highways.

\section{Urban Infrastructure}

Investment required: $\$ 3.6$ billion

- Eleven cities have been shortlisted as growth centers across employment zones. Each city requires comprehensive upgrade of drainage and sewerage infrastructure.

- Development of common effluent treatment plants is required close to industrial and urban growth centers.

\section{Railways and Logistics}

Investment required: $\$ 3.2$ billion

- Last-mile connectivity to Eastern Dedicated Freight Corridor needs to be prioritized.

- Rail electrification in eastern and Bundelkhand zones is critical for both passenger and freight movement. 
- Three new multimodal logistics hubs (freight villages) are required in Varanasi, Bhaupur, and Dadri.

\section{Airports}

Investment required: $\$ 2.6$ billion

- Capacity augmentation at Lucknow and Varanasi airports is required.

- Significant upgrade of Gorakhpur, Kanpur, and Allahabad Airports is needed.

\section{Power Supply}

Investment required: $\$ 1$ billion

- Energy supply may be augmented through renewable sources like solar power.

- Electricity distribution infrastructure may be upgraded by setting up new substations, adopting high voltage distribution systems, and using aerial bundled conductors.

\section{Skill Development}

Investment required: \$155.4 million

- Specialized centers of excellence for priority sectors may be developed.

- Existing government training and education infrastructure may be upgraded and better utilized.
- Teachers' training, learning, and professional development may be focused upon.

- A state government institution for assessment and certification of trainees may be developed.

- Industry linkages of training institutions, particularly with MSMEs, may be strengthened.

- Capacity development within the Uttar Pradesh Skill Development Mission may be prioritized.

\section{CONCLUSION}

Uttar Pradesh is home to nearly 200 million people, of which about 30\% live below the poverty line..$^{18}$ Agriculture still remains the primary livelihood option for the majority of the working population. Structural transformation of the state, and a significant shift in the economic structure is necessary for it to generate gainful and productive employment opportunities outside agriculture. In this context, manufacturing (particularly MSMEs) with its high employment elasticity needs to be provided greater support through ease of doing business measures and better infrastructure. This study proposes an investment plan and recommends priority projects across transport, energy, urban, and skilling infrastructure to unlock efficiencies, improve competitiveness, and enhance value addition for putting Uttar Pradesh firmly on a fast-tracked inclusive growth path.

18 World Bank. 2016. Uttar Pradesh - Poverty, Growth and Inequality (English). India State Briefs. Washington, D.C. : World Bank Group. http://documents. worldbank.org/curated/en/187721467995647501/Uttar-pradesh-Poverty-growth-and-inequality.

About the Asian Development Bank

$A D B$ is committed to achieving a prosperous, inclusive, resilient, and sustainable Asia and the Pacific, while sustaining its efforts to eradicate extreme poverty. Established in 1966, it is owned by 68 members -49 from the region. Its main instruments for helping its developing member countries are policy dialogue, loans, equity investments, guarantees, grants, and technical assistance.

ADB Briefs are based on papers or notes prepared by ADB staff and their resource persons. The series is designed to provide concise, nontechnical accounts of policy issues of topical interest, with a view to facilitating informed debate. The Department of Communications administers the series.

\begin{abstract}
The views expressed in this publication are those of the authors and do not necessarily reflect the views and policies of ADB or its Board of Governors or the governments they represent. ADB encourages printing or copying information exclusively for personal and noncommercial use with proper acknowledgment of ADB. Users are restricted from reselling, redistributing, or creating derivative works for commercial purposes without the express, written consent of ADB
\end{abstract}

\author{
Asian Development Bank \\ 6 ADB Avenue, Mandaluyong City \\ 1550 Metro Manila, Philippines \\ Tel +63286324444 \\ Fax +63286362444 \\ www.adb.org/publications/series/adb-briefs
}

